\begin{tabular}{|l|l|l||}
\hline \multicolumn{2}{|c|}{ PublisherInfo } \\
\hline \hline PublisherName & $:$ & BioMed Central \\
\hline \hline PublisherLocation & $:$ & London \\
\hline \hline PublisherImprintName & $:$ & BioMed Central \\
\hline \hline
\end{tabular}

\title{
Processing ribosomal RNA
}

\begin{tabular}{|l|c|l||}
\hline \multicolumn{2}{|c|}{ ArticleInfo } \\
\hline \hline ArticleID & $:$ & 4502 \\
\hline \hline ArticleDOI & $:$ & $10.1186 /$ gb-spotlight-20020612-02 \\
\hline \hline ArticleCitationID & $:$ & spotlight-20020612-02 \\
\hline \hline ArticleSequenceNumber & $:$ & 168 \\
\hline \hline ArticleCategory & $:$ & Research news \\
\hline ArticleFirstPage & $:$ & 1 \\
\hline \hline ArticleLastPage & $:$ & 2 \\
\hline \hline & & RegistrationDate : 2002-6-12 \\
\hline ArticleHistory & $:$ & OnlineDate \\
\hline \hline ArticleCopyright & $:$ & BioMed Central Ltd2002-6-12 \\
\hline \hline ArticleGrants & $:$ & \\
\hline \hline ArticleContext & $:$ & 130593311 \\
\hline \hline
\end{tabular}




\section{Jonathan B Weitzman}

Email: jonathanweitzman@hotmail.com

The U3 small nucleolar RNA (snoRNA) was discovered over 30 years ago, but its precise function and molecular partners have remained unclear. In an Advanced Online Publication in Nature, Dragon et al. describe the purification of a large ribonucleoprotein (RNP) complex from Saccharomyces cerevisiaeand report that it contains U3 snoRNA together with 28 proteins, ranging from 13 to $200 \mathrm{KDa}$ (9 June 2001, DOI:10.1038/nature00769). They took a protein-based affinity purification approach using epitope-tagged components. The purified components include known U3 snoRNA-associated proteins (such as Nop1 and Sof1) and 17 new proteins (named Utp1-Utp17). Eleven of the novel Utps may have human homolog, suggesting strong conservation of the mechanisms of pre-rRNA processing. The Utp proteins are localized in the nucleolus and could be immunoprecipitated with U3 sno-RNA. Systematic depletion of each of the 17 Utp proteins resulted in reduced 18S rRNA levels, demonstrating that they are necessary for the biogenesis of small ribosomal subunit RNA. The authors conclude that the active U3 particle is not a small nucleolar complex but rather a large nucleolar RNP. The complex is important for early ribosome biogenesis and pre-18S rRNA processing, so they have named it the small subunit (SSU) processome.

\section{References}

1. Small molecular weight monodisperse nuclear RNA.

2. Nature, [http://www.nature.com]

This PDF file was created after publication. 